Comparative Philosophy Volume 1, No. 1 (2010): 78-89

Open Access / ISSN 2151-6014

http://www.comparativephilosophy.org

\title{
TYPOLOGY OF NOTHING: HEIDEGGER, DAOISM AND BUDDHISM
}

\author{
ZHIHUA YAO
}

\begin{abstract}
Parmenides expelled nonbeing from the realm of knowledge and forbade us to think or talk about it. But still there has been a long tradition of nay-sayings throughout the history of Western and Eastern philosophy. Are those philosophers talking about the same nonbeing or nothing? If not, how do their concepts of nothing differ from each other? Could there be different types of nothing? Surveying the traditional classifications of nothing or nonbeing in the East and West have led me to develop a typology of nothing that consists of three main types: 1) privative nothing, commonly known as absence; 2) negative nothing, the altogether not or absolute nothing; and finally 3) original nothing, the nothing that is equivalent to being. I will test my threefold typology of nothing by comparing the similarities and differences between the conceptions of nothing in Heidegger, Daoism and Buddhism. These are three of the very few philosophical strains that have launched themselves into the wonderland of negativity by developing respectively the concepts of nothing (Nichts), nothing (wu 無) and emptiness (śūnyatā). With this analysis, I hope that I will clarify some confusion in the understanding of nothing in Heidegger, Daoism and Buddhism, and shed light on the central philosophical issue of "what there is not".
\end{abstract}

Keywords: nothing, absence, Heidegger, Daoism, Buddhism

\section{INTRODUCTION}

Parmenides expelled nonbeing from the realm of knowledge and forbade us to think or talk about it. But still there has been a long tradition of nay-sayings throughout the history of Western and Eastern philosophy. Are those philosophers talking about the same nonbeing or nothing? If not, how do their concepts of nothing differ from each other? Could there be different types of nothing?

Leibniz once famously argued against the possibility of there being more than one void. He maintains that if there could be more than one void, then there could be two voids of exactly the same shape and size. These two voids would be perfect twins (Sorensen 2009, sec. 9). Leibniz's argument suggests that if we are dealing with empty space, then a type of nothing potentially has "shape" or "size". But the variety of traditional conceptions of nothing is much more complicated than this.

YAO, ZHIHUA: Associate Professor, Department of Philosophy, the Chinese University of Hong Kong. Email: zyao@cuhk.edu.hk 
Surveying the traditional classifications of nothing or nonbeing in the East and West have led me to develop a typology of nothing that consists of three main types: 1) privative nothing, commonly known as absence; 2) negative nothing, the altogether not or absolute nothing; and finally 3 ) original nothing, the nothing that is equivalent to being. I do not claim that these exhaust the types of nothing in which many other philosophers had more finely grained classification schemes. For instance, the Neo-Platonist Ammonios Hermeiu and the Indian Yogācārins distinguished five different types of nothing, whereas Marius Victorinus (another Neo-Platonist), Immanuel Kant, and mainstream Indian philosophy had developed various fourfold schemes. However, I think my typology will suffice for the purpose of my paper which is to examine the similarities and differences between the conceptions of nothing in Heidegger, Daoism and Buddhism. The reason why I choose these three philosophical strains to test my typology of nothing is not only because I am familiar with them, but also because they each respectively represent the developing concepts of nothing in the West, China and India.

The logical positivist Rudolf Carnap once criticized the Western tradition of metaphysics by taking Heidegger's theory of nothing as an extreme case of meaningless discourse (Carnap 1931, 233). Similarly, in the eyes of orthodox Confucian and Hindu scholars, both Daoism and Buddhism were seen as passive, negative, and even destructive to intellectual and social norms. In fact, these scholars condemned them as heresies and were determined to eliminate their influence on Chinese and Indian minds. It is no accident that their opponents developed a "negative" impression of these traditions. These are three of the very few philosophical strains that have launched themselves into the wonderland of negativity by developing respectively the concepts of nothing (Nichts), nothing ( $w u$ 無) and emptiness (śūnyatā).

\section{ORIGINAL NOTHING}

In his major work Being and Time, Heidegger apparently did not treat nothing as a central issue. Only in his analysis of Angst, one of the fundamental attunements (Befindlichkeit) of Dasein, does he touch upon this concept. The idea of Angst is deeply rooted in the Judeo-Christian tradition. In a long footnote in section 40 on "The fundamental attunement of Angst as an eminent disclosedness of Da-sein", Heidegger refers to Augustine, Luther and Kierkegaard to support his distinction between Angst and fear (Furcht). With regard to Angst, Heidegger says:

The fact that what is threatening is nowhere characterizes what Angst is about. Angst "does not know" what it is about which it is anxious. But "nowhere" does not mean nothing; rather, region in general lies therein, and disclosedness of the world in general for essentially spatial being-in. Therefore, what is threatening cannot approach from a definite direction within nearness, it is already "there" - and yet nowhere. It is so near that it is oppressive and stifles one's breath - and yet it is nowhere. In what Angst is about, the "it is nothing and nowhere" becomes manifest (Heidegger 1963, 186; Stambaugh 1996, 174-5).

It is nothing (Nichts) and nowhere (nirgends), and yet the disclosedness of the world lies within it. This reminds us of God being depicted in negative terms within 
the mystical Christian tradition. In contrast to the philosophical discussions of nothing, as found in early western philosophers, such as Parmenides and Plato, the Christian mystics who developed the negative theology regard nothing as an experience. Their view has influenced many classical German philosophers including Schelling and Hegel. In this sense, nothing is not an abstract concept, but rather a reality that can be experienced. This is similar to the Eastern mystical tradition of Daoism that emphasizes the sagely practice of experiencing nothing (shengren $t i w u$ 聖人體無).

Of course, it is not so easy to experience nothing. In fact, Heidegger admits that such an experience is rare. In Heidegger's What is Metaphysics, he states: "Does such an attunement, in which man is brought before the nothing itself, occur in human Dasein? It can and does occur, although rarely enough and only for a moment, in the fundamental mood of Angst." (Heidegger 1978, 111; 1998, 88, with my modification) In this work of 1929, we find the most extensive discussion of nothing by Heidegger. Most of the work illustrates how nothing is revealed and experienced in Angst. Moreover, he develops another theme that is not seen in Being and Time which is the relationship between being and nothing. He says, "nothing does not remain the indeterminate opposite of beings but unveils itself as belonging to the being of beings". (Heidegger 1978, 120; 1998, 94) Furthermore, he states that "[i]n the being of beings the nihilation (Nichten) of nothing occurs". (Heidegger 1978, 115; 1998, 91) We can infer from these statements that Heidegger takes nothing to be equivalent to being.

The idea that nothing and being is equivalent can be found in many of Heidegger's works. For instance, "Being: Nothing: Same...Nothing is the characteristic (Kennzeichnung) of Being". Reinhard May, who studied these expressions, tries to prove their connection with relevant statements that are found in Daoism and Chan Buddhism. These statements include: "Being and nothing giving rise to each other" (Dao-De-Jing Ch. 2); "The things of the world arise from being. And being arises from nothing" (Dao-De-Jing Ch. 40); "Being is none other than nothing, nothing is none other than being" (Xin-Xin-Ming 信心銘, T2023, 1056a). May maintains that all of these Daoist and Chan Buddhist writings were already translated into German in or before the 1920s, and so Heidegger may have read these sources and become influenced by them (May 1996, 26-8).

Heidegger, however, only admits Hegel's contribution on this point. He cites a statement from Hegel's Science of Logic: "Pure being and pure nothing are the same." Pure being and pure nothing are two concepts in the beginning of Hegel's logical system. They are the same because they are indeterminate, immediate and pure. But Heidegger disagrees with Hegel on how and why they are the same. He says: "Being and nothing do belong together, not because both - from the point of view of the Hegelian concept of thought - agree in their indeterminateness and immediacy, but rather because being itself is essentially finite and manifests itself only in the transcendence of a Dasein that is held out into nothing." (Heidegger $1978,120 ; 1998,94-5)$ Here "the transcendence of Dasein" is discussed earlier in the same work: "Being held out into nothing - as Dasein is - on the ground of concealed Angst is its surpassing of beings as a whole. It is transcendence."

${ }^{1}$ For more examples, see May 1996, 21-6. 
(Heidegger 1978, 118; 1998, 93) Dasein transcends the totality of beings and therefore reaches the being itself. Meanwhile, Dasein is also "held out" into nothing, therefore being and nothing become identical in the experiential dimension of Dasein.

Another theme that Heidegger devoted himself to is the relationship between nothing and negativity, a concept again bearing a Hegelian mark. In Hegel's system, negativity is apparently more active and important than pure nothing. It is the engine of the Hegelian dialectics and makes becoming, movement and development possible through its force of Aufhebung. Although Heidegger insists that "nothing is the origin of negation, not vice versa" (Heidegger 1978, 117; 1998, 86), he closely follows Hegel when he describes how nothing functions through negation and refusal. We can see this in two of Heidegger's works that were written in the 1930s but only recently published.

Fullness is pregnant with the originary "not"; making full is not yet and no longer gifting, both in counter-resonance, refused in the very hesitating, and thus the charming-moving-unto in the removal-unto in the removal-unto. Here [is] above all the swaying not-character of be-ing as enowning (Heidegger 1999, 189).

The questioning of the history of being not only experiences nothing not as void (Nichtiges), when this questioning requests the being itself in the fullness of its essential swaying, nothing is experienced as enownment (Er-eignung) (Heidegger 1997, 313. My translation).

Here enowning (Ereignis) or enownment (Ereignung) functions as the provider or giver of being and time, and it is the 'it' in the phrase "it gives/there is" (es gibt). Meanwhile, Heidegger stresses that the withdrawal or refusal that is not providing or giving also belongs essentially to the enowning itself. It is this withdrawal or refusal that makes providing or giving possible. Therefore, in the withdrawal or refusal that is located in the heart of enowning, we see an original nothing which is the ultimate ground for negation and negativity.

The term "original nothing" (nihil originarium) appears in Heidegger's writings only a few times. For instance, when discussing the world as nothing, he says: "The world is the nothing that originally temporalizes itself and simply arises in and with the temporalizing (Zeitigung). We, therefore, call the world the original nothing (nihil originarium)."2 Nevertheless, this term captures very well the basic meaning of nothing in Heidegger's usage, namely, as something experienced by Dasein's Angst, equivalent to being, and functioning through negation and withdrawal.

By using "original nothing" Heidegger also distances himself from other types of nothing that were discussed by previous philosophers. It is generally agreed that what Parmenides forbade us to talk about is "the altogether not" ( $\tau \dot{\delta} \mu \eta \delta \alpha \mu \tilde{n}$ $\mu \eta \delta \alpha \mu \tilde{\omega} \varsigma$ oै $v)$. Since Plato philosophers have tried to break this curse, but they were only approaching an "absence". In Kant's fourfold classification of nothing, these two senses of nothing are respectively called negative nothing (nihil negativum) and privative nothing (nihil privativum). He characterizes the former as "the empty

\footnotetext{
2 Heidegger 1990, 271. Cited from Wirtz 2006, 333. My translation. For more discussions on this concept, see Kwan 1982, 76, 83-84, and 142.
} 
object without concept" that is the impossible, e.g., a two-sided rectilinear figure, and the latter as "the empty object of a concept", e.g., a shadow or cold. ${ }^{3}$ For many philosophers, these are the two basic types of nothing. I therefore take them to be the first two types in my classification scheme. But Heidegger's sense of original nothing seems to have nothing to do with them. Instead, this nothing signifies alternatively to his key concept of being. Nothing as being is also one of the four types of nothing for the Neo-Platonist, Marius Victorinus. ${ }^{4}$ Its traces can be found in many classical German thinkers such as F.H. Jacobi, J.G. Hamann, Schelling, Hegel, and F. von Baader. So, I include original nothing as the third type of nothing in my classification scheme. With these three types of nothing in mind, we can now discuss the Daoist concept of nothing.

\section{NOTHING}

In early Daoism, nothing may not have been a central concept as "Dao" but even at this stage it is an essential aspect of Dao. Its position was further elevated with the development of the Xuan School. The Neo-Confucian scholars, also known as "Dao-scholars", were not necessarily upset by the idea of Dao, but often reacted strongly against nothing. Nothing may not be the central concept of Daoist philosophy, but it is surely the most characteristic Daoist concept.

According to Pang (1999, 348-63), the concept of nothing as discussed in the rich canons of Chinese philosophy can be classified as having three different types. These include "nothing as absence", "absolute nothing", and "nothing as being" which are signified respectively by the characters 'wang' (亡), 'wu' (无) and ' $w u$ ' (無). Interestingly, these three types correspond to the three major types of nothing that I identified among Western philosophers, namely, privative nothing (nihil privativum), negative nothing (nihil negativum) and original nothing (nihil originarium). It is now pertinent to consider what type of nothing the Daoists were talking about.

Many contemporary scholars distinguish two senses of nothing in Lao Zi's Dao-De-Jing. ${ }^{5}$ One is the empirical or commonsense usage referring to empty space. This usage is found especially in Chapter 11 of the Dao-De-Jing, where nothing functions inside the hub, a pot, and the dwelling. The other is nothing in its metaphysical sense, referring to the source or origin of all existents, and found in key passages of the Dao-De-Jing, e.g., Chapters 2 and $40 .^{6}$ This distinction, however, becomes irrelevant if we attempt to match Daoist nothing to my typology of nothing. Both space and the origin of all existents are actual existence with real

\footnotetext{
3 See Kant 1956, 332-3. The other two types are rational entity (ens rationis) and imaginary entity (ens imaginarium).

${ }^{4}$ See Kobusch 1984, 809. The other three types are negation, mutual relation, and the not-yet existent (Noch-nichtsein). Another Neo-Platonist Ammonios Hermeiu added the fifth ineffable unrepresentable nothing to the list.

5 For instance, Liu 1997, 159; Wang 2001, 155; Lin 2007, 151.

${ }^{6}$ I exclude chapter 1, because I read the relevant sentence there as "the nameless (wuming 無名) is the origin of heaven and earth" rather than "nothing ( $w u$ 無) is called (ming 名) the origin of heaven and earth".
} 
function. They are called nothing only because they are formless and imageless. So nothing for Lao $\mathrm{Zi}$, either in its empirical or metaphysical sense, is the "nothing as being" or the original nothing.

In the Dao-De-Jing, there are also a large number of compounds in the form of “non- $x$ ” or “no- $x$ ", e.g., non-action (wu-wei 無爲) and no-name (wu-ming 無名), where the word 'wu' ('non-', 'no-') functions as a prefix in the compound and cannot act independently as a noun or a philosophical concept. Its meaning is close to the privative nothing or nothing as absence. The Daoist classics never seem to mention the absolute or negative nothing, which usually indicates logical impossibility as in the case of late Moist classics. ${ }^{7}$

In any case, the concept of nothing as discussed in the Daoist philosophical context falls under the category of original nothing or nothing as being. It is elaborated in two aspects. The first is the cosmogonical or vertical dimension, with the emphasis of nothing being the source or origin of existents: "The things of the world arise from being. And being arises from nothing." ${ }^{8}$ It is this ability of giving rise to all existents that makes nothing the true original nothing. The same idea is elaborated in the Zhuang-Zi: "The myriad things come forth from nonbeing. Being cannot bring being into being; it must come forth from nonbeing, and nonbeing is singularly nonbeing." The Xuan School, represented by Wang Bi, further develops this line of thinking and interprets nothing as the "origin" (ben 本) of all things. In comparison to its Western counterparts, the Daoist nothing is more "original" by emphasizing its cosmogonical dimension.

The second is the ontological or horizontal dimension that emphasizes "being and nothing giving rise to each other". ${ }^{10}$ The mutual arising of being and nothing horizontally illuminates the identity and transformation between pure being and pure nothing. The formless imageless original nothing, through its identity with and transformation into being, establishes its ontological position in the sense of nothing as being. This runs parallel to the ontologies of Hegel and Heidegger.

Certain tension exists between the two dimensions, however, and many commentators have attempted to explain the apparent contradiction. In my view, the failure of classical Chinese philosophers, such as $\mathrm{Lao} \mathrm{Zi}$, to distinguish ontology from cosmology or cosmogony contributes to this tension. The admixture of cosmogonical and ontological approaches that dominates classical Chinese philosophy probably owes its existence to the centrality of sheng (生) (begetting, generating, giving rise to) in Daoist and Confucian metaphysics. Exactly for the same reason, original nothing in Lao $\mathrm{Zi}$ and Daoist philosophy is realized in its more complete "original" form than in the works of Western philosophers such as Heidegger, who only stress its ontological dimension.

\footnotetext{
${ }^{7}$ See the Mojing and its commentary: 無不必待有, ......無天陷, 則無之而無 (Nonbeing does not necessarily presuppose being. ... In the case the nonbeing of the sky's falling down, it is nonbeing without ever having been).

${ }^{8}$ Dao-De-Jing, Chapter 40: 天下萬物生於有, 有生於無.

${ }^{9}$ Zhuang-Zi, Chapter of “Geng-Sang-Chu”: 萬物出乎無有, 有不能以有為有, 必出乎無有, 而 無有一無有.

${ }^{10}$ Dao-De-Jing, Chapter 2: 有無相生.
} 


\section{EMPTINESS}

Let us turn to emptiness in Buddhist philosophy and its relationship to nothing. In early and sectarian Buddhism, the concept of emptiness was employed to interpret the foundational Buddhist doctrine of no-self. It became one of the key Buddhist concepts with the rise of Perfection of Wisdom literature and its interpretation by the Madhyamaka scholars. The orthodox Hindu scholars, who often classified Buddhist philosophy into four major schools, namely, Sarvāstivāda realism, Sautrāntika indirect realism, Yogācāra idealism, and Madhyamaka nihilism, were especially critical of the latter. In their view, emptiness may not have been the central concept of Buddhism, but it was no doubt the most characteristic of Buddhist philosophy.

In the history of Indian philosophy, different schemes were developed for classifying nothing or nonbeing $(a b h \bar{a} v a)$. The mainstream Vaiśeșikas, Naiyāyikas, and Mīmāṃsākas classified nonbeing into four types, namely, prior nonbeing (prāgabhāva), posterior nonbeing (dhvamsāahhāva), mutual nonbeing (anyon$y \bar{a} b h \bar{a} v a$ ), and absolute nonbeing (atyantābhāva). These four types can be subsumed into two more basic types: absolute nonbeing and mutual nonbeing. The latter covers the first three of four types, which are its manifestations in temporal and spatial dimensions. Mutual nonbeing corresponds to privative nothing or absence in my typology, while absolute nonbeing is the negative nothing with respect to "the altogether not". This popular scheme, however, does not include emptiness. Among the Indic sources that I have encountered, only a Yogācāra Buddhist text adds emptiness to the scheme as the fifth type of nonbeing. It is called the "ultimate nonbeing" (paramärthāsat) and interpreted as "devoid of intrinsic nature" (nihsvabhāva), which is exactly the definition of emptiness. ${ }^{11}$

In the history of Buddhism the Madhyamaka and Yogācāra traditions have developed an interpretation of emptiness. It is generally agreed that the Perfection of Wisdom literature and its Madhyamaka interpretation, while aiming at criticizing and denying intrinsic nature, made emptiness a central Buddhist concept. Intrinsic nature (svabhāva) was a key concept in Abhidharma scholasticism that characterized the unanalysable elements (dharma) of all existents. In this understanding, the intrinsic nature of each and every element should be distinctive and consistent, otherwise their distinction will collapse. Meanwhile, their consistent, even permanent, nature does not imply that existents made of elements do not go through change or transformation. All the elements and existents, as long as they are conditioned, must dependently arise and cease.

In the Madhyamaka view, however, the concept of intrinsic nature is incompatible with the foundational Buddhist doctrine of dependent arising. Nāgārjuna argues, "[t]he origination of intrinsic nature from causes and conditions is illogical, since intrinsic nature originated from causes and conditions would become contingent. How could there be contingent intrinsic nature? Intrinsic nature is not contingent, nor is it dependent on others." ${ }^{2}$ By upholding the doctrine of

\footnotetext{
11 It is found in the encyclopedic Yogācārabhūmi (T1579, 362c) and its commentaries (T1828, 416a and T1829, 97a).

${ }^{12}$ Mülamadhyamakakārikā 16.1-2: na saṃbhavaḥ svabhāvasya yuktaḥ pratyayahetubhiḥ /
} 
dependent origination, one must give up and deny intrinsic nature, as Nāgārjuna declares: "Whatever is dependently originated, I claim it is emptiness." ${ }^{13}$ He holds that all those in the net of causal arising-either conventional existence or its elements - are devoid of intrinsic nature and empty. For the Ābhidharmikas, such conventional existence-for instance, a desk or person-is conceptually constructed, and hence lack intrinsic nature, but their building blocks are those elements embedded with intrinsic nature. Nāgārjuna insists that even those building blocks, as long as they arise and cease in the causal network, are also "conceptually constructed". ${ }^{14}$

There are at least two ways of understanding this claim of emptiness. If all existents are conceptually constructed, as with illusions and hallucinatory objects, then emptiness in this sense is absolute or negative nothing as in the case of the son of a barren woman or square-circle, both indicating logical impossibility. This will inevitably lead to a nihilist end that negates all existents, which, as a matter of fact, dominates classical and contemporary interpretations of the Madhyamaka tradition. ${ }^{15}$ The other way, however, emphasizes that absolute reality such as dharma-realm (dharmadhätu) or thusness (tathatā) is revealed through the idea of emptiness that denies intrinsic nature. ${ }^{16}$ In this view, emptiness comes close to original nothing or nothing as being. Nāgārjuna himself seems unwilling to fall into either extreme when he claims that emptiness is "the middle way" 17 which is beyond nonbeing and being. From the viewpoint of my typology of nothing, if emptiness is beyond negative nothing (the extreme of nonbeing) and original nothing (the extreme of being), then it would fall under privative nothing. This observation is supported by the very definition of emptiness as "devoid of intrinsic nature" which is a constant negation and antidote of any reification, even emptiness itself, and therefore "emptiness is empty". ${ }^{18}$

In the Yogācāra School, even though emptiness is not as central as it is in the Madhyamaka School, the Yogācārins understood it very differently. They refer to a passage from an early Buddhist text, Cūlasuñnata-sutta, which is never cited by the Mādhyamikas in their extensive discussion on emptiness. The text says: "It is seen that when something does not exist somewhere, that place is empty with regard to the former. And yet it is to be understood that when something remains somewhere it does exist as reality." 19 In this case, emptiness is understood in terms of privation or absence, or, in an Indian term, mutual nonbeing. But this type of nonbeing is always relative to something existent. It is in this sense that emptiness serves as an antidote to intrinsic nature in Madhyamaka. But when emptiness is expanded to negate all existents at the ultimate level, it will cease to be a mutual nonbeing in the

hetupratyayasaṃbhūtaḥ svabhāvah krtako bhavet // svabhāvaḥ kṛtako nāma bhaviṣati punaḥ katham / akrtrimah svabhāvo hi nirapekșah paratra ca /l.

13 Mūlamadhyamakakārikā 24.18ab: yaḥ pratītyasamutpādaḥ śūnyatām tām pracakșmahe /.

${ }_{14}$ Mūlamadhyamakakārikā 24. 18c: sā prajñaptir upādāya pratipat.

15 Contemporary scholars with this approach are represented by Eugene Burnouf, H. Jacobi, M.

Walleser, I. Wach, A.B. Keith, and La Vallee Poussin. See Lin 1999, 183-6.

16 Contemporary representatives of this approach are St. Schayer, Stcherbatsky, and Murti. See Lin 1999, 186-91.

17 Mülamadhyamakakārikā 24. 18d: saiva madhyamā //.

18 See Pingala's commentary on the Mülamadhyamakakārikā, T1564, 33 b17.

19 Cited from Nagao 1991, 210. 
sense of absence and become an absolute negative nonbeing. The Mādhyamikas themselves may not admit this, but their theory inevitably leads to this end.

The Yogācārins understood emptiness in terms of its root meaning of absence and defined "the characteristic of emptiness as nonbeing of subject and object and the being of that nonbeing" ${ }^{20}$ The subject and object, in their epistemologically oriented project, is regarded as conceptual constructions on the basis of existent conscious processes. The concept of emptiness denies the existence of these conceptual constructions, yet asserts the existence of consciousness (vijñāna), thusness (tathatā), or dharma-realm (dharmadhātu). In this respect, emptiness is equivalent to the so-called “wondrous being" (miao-you 妙有) and therefore comes close to the original nothing or nothing as being in my typology of nothing.

Later Tibetan Buddhists characterized the Yogācāra way of understanding emptiness as "other-emptiness" (gzhan stong), in contrast to the "self-emptiness" (rang stong) held by the Mādhyamikas, and condemned the former way of understanding as heresy. This understanding of emptiness as wondrous being, however, became dominant in East Asian Buddhism, a development based on the influence of the Yogācāra as well as the Daoist sense of original nothing. As a result, Buddhist emptiness and Daoist nothing were easily confused. ${ }^{21}$ Masao Abe (1985, 128-30), for instance, while discussing the superiority of negativity in Eastern philosophy, treated Daoist nothing and Buddhist emptiness as equivalent to wondrous being. In his discussion, both are understood to be original nothing or nothing as being.

\section{CONCLUSION}

By comparing the similarities and differences between the concept of nothing in Heidegger, Daoism and Buddhism, I have tested my threefold typology of nothing. If we distinguish the conceptions of nothing into three basic types, namely, privative, negative, and original nothing, then Heidegger's and Daoism's conception of nothing can be characterized as "original nothing". The unique Daoist cosmogonical-ontological approach renders nothing more "original" than its parallels in Western philosophy. In contrast, the emptiness in Madhyamaka Buddhism is basically a type of privative nothing, but its tendency to negate all existents at the ultimate level leads to negative nothing. And finally, the emptiness in Yogācāra Buddhism is basically nothing as absence or privation, but its affirmation of ultimate reality leads to original nothing. The latter sense of emptiness was more influential among East Asian Buddhists, and more easily confused with the Daoists' original nothing.

With this analysis, I hope that I have clarified some confusion in the understanding of nothing in Heidegger, Daoism and Buddhism. This typology of nothing also sheds light on the central philosophical issue of "what there is not". The perplexity of this issue is attributed to the fact that nonbeing or nothing, by its very nature, escapes from falling into a being or something and thus resists any

${ }^{20}$ Madhyāntavibhāga I.13ab: dvayābhāvo hy abhāvasya bhāvaḥ śūnyasya lakṣaṇam /.

21 See the relevant studies in Luo 2003 and Zhao 2007. 
attempt of definition or characterization. In the history of Western philosophy, the mystery of nothing is usually associated with two equally mysterious questions. One is why, according to Parmenides, can we not think or talk about nonbeing? This question becomes even more intriguing in contrast to the fact that we can talk about nonbeing or nothing with ease in our ordinary language. The other is the famous Leibnizian-Heideggerian question: "Why is there something rather than nothing?" which has been taken to be the fundamental question of metaphysics.

According to my typology of nothing, when Parmenides forbade us from thinking or talking about nonbeing, he was warning us against the altogether not or absolute nothing, e.g., square-circle and the son of a barren woman. It is evident that this type of nothing was mainly a logician's concern, including Moists, Hindu and Buddhist logicians, and contemporary analytical philosophers since Russell. Given its nature of being logically contradictory and impossible, this type of nothing, as predicted by Parmenides, does not really enter into the realm of knowledge, but rather functions as an indicator of the limit of human knowledge. What does enter the realm of our knowledge and ordinary language is a different type of nothing. To break the curse of Parmenides, Plato and his followers were approaching "what there is not" in the sense of "difference" or, in Indian terminology, mutual nonbeing. As the absence or privation of being, this type of nothing is always an essential part of our knowledge. So the reason that we can think or talk about nonbeing or nothing with ease is not because Parmenides was wrong, but because we are approaching a different interpretation of nothing.

Leibniz was the first philosopher to put forward the perplexing metaphysical question: "Why is there something rather than nothing?" Various attempts to answer this question have understood nothing as an absolute nothing that is logically impossible. As a result, the existence of something is believed to have a higher probability or necessity. The question then becomes purely speculative, as if it is possible for a state of absolute nothing to exist prior to something. However, if we understand nothing in the Heideggerian or Daoist sense of original nothing, then the question is a matter of cosmogony, i.e., how a concrete something with form and image comes about from a formless imageless state. To answer this, Christian theologians would resort to God's will, whereas Daoists would rely on the creativity of Dao. In either case, nothing should not be understood as absolute nothing or absence; such an interpretation will lead to vain speculations. Instead, nothing is a formless imageless state of existence, which is described as earth and water covered with darkness in the Book of Genesis, or simply as chaos in Daoist writings. It is only with this conception of nothing that we can make sense of this fundamental question of metaphysics.

I have expounded my typology of nothing by comparing the conceptions of nothing in Heidegger, Daoism and Buddhism (three representative philosophical trends in the West, China and India). Each has explored negativity to a great depth and preliminarily answers two perplexing questions in the philosophical discourse of nothing, i.e., "why we cannot think or talk about nothing" and "why there is something rather than nothing". The depth of these discussions shows that it is wrong to indiscriminately exclude all kinds of nothing from the proper realm of philosophy. Instead we should treat the subject more seriously by engaging with traditional sources in the East and West with the hope that we may eventually know 
better "what there is not".

\section{ACKNOWLEDGEMENTS}

Earlier version of the paper has been presented in a conference in Hong Kong. For its current revised version, I am grateful to the constructive remarks and suggestions of three anonymous reviewers.

\section{REFERENCES}

Abe, Masao (1985), "Non-being and $M u$ - the Metaphysical Nature of Negativity in the East and the West", in William R. LaFleur (ed.), Zen and Western Thought (London: Macmillan), pp. 128-30.

Carnap, Rudolf (1931), "Überwindung der Metaphysik durch logische Analyse der Sprache," Erkenntnis 2: 219-41.

Heidegger, Martin (1963), Sein und Zeit (Tübingen: Max Niemeyer Verlag).

--- (1978), "Was ist Metaphysik?" in Wegmarken, GA 9 (Frankfurt am Main: Vittorio Klostermann).

---- (1990), Metaphysische Anfangsgründe der Logik im Ausgang von Leibniz, GA 26 (Frankfurt am Main: V. Klostermann).

---- (1997), Besinnung, GA 66 (Frankfurt am Main: V. Klostermann).

---- (1998), Patmarks, edited by William McNeill (Cambridge and New York: Cambridge University Press).

---- (1999), Contributions to philosophy (from enowning), translated by Parvis Emad and Kenneth Maly (Bloomington, Ind.: Indiana University Press).

Kant, Immanuel (1956), Kritik der reinen Vernunft (Hamburg: Verlag von Felix Meiner).

Kobusch, Theo (1984), "Nichts, Nichtseiendes", in Historisches Wörterbuch der Philosophie (Basel and Stuttgart: Schwabe \& Co AG Verlag), Band 6, pp. 813-9.

Kwan, Tze-wan (1982), Die hermeneutische Phänomenologie und das tautologische Denken Heideggers (Bonn: Bouvier Verlag Herbert Grundmann).

Lin, Chen-Kuo (1999), Kong-Xing-Yu-Xian-Dai-Xing: Cong-Jing-Du-Xue-Pai, Xin-Ru-Jia-Dao-Duo-Yin-De-Fo-Jiao-Quan-Shi-Xue [Emptiness and Modernity: From Kyoto School, New Confucianism to Buddhist Hermernitcs] (Taipei: Li-Xu-Wen-Hua-Shi-Ye-You-Xian-Gong-Si)

Lin, Chien-Te (2007), "Lao-Zi-Yu-Zhong-Lun-Zhi-Zhe-Xue-Bi-Jiao" [A Comparison between the Philosophies of the Lao-Zi and the Mūlamadhyamakakārikā], Dissertation, National Taiwan University. Liu, Xiaogan (1997), Lao-Zi [Lao Zi] (Taipei: Dong-Da-Tu-Shu-Gong-Si).

Luo, Yin (2003), Kong-You-Yu-You-Wu: Xuan-Xue-Yu-Ban-Ruo-XueJiao-Hui-Wen-Ti-Zhi-Yan-Jiu [Emptyness versus Being and Being versus Nothing: A Study of the Relationship between Dark Learning and Wisdom Learning] (Taipei: Guo-Li-Taiwan-Da-Xue-Chu-Ban-Wei-Yuan-Hui).

May, Reinhard (1996), Heidegger's Hidden Sources: East-Asian Influences on His 
Work, translated with a complementary essay by Graham Parkes (London and New York: Routledge).

Nagao, Gajin (1991), Mādhyamika and Yogācāra: A Study of Mahāyāna

Philosophies, edited, collated, and translated by L.S. Kawamura in

collaboration with G.M. Nagao (Albany: State University of New York Press).

Pang, Pu (1999), "Shuo-'Wu"' [On "Nothing"], in Dang-Dai-Xue-Zhe-Zi-Xuan-

Wen-Ku: Pang-Pu-Juan [Selected Works of Contemporary Scholars: Pang Pu]

(Hefei: Anhui-Jiao-Yu-Chu-Ban-She), pp. 348-63.

Sorensen, Roy (2009), "Nothingness", in Stanford Encyclopedia of Philosophy <http://plato.stanford.edu/entries/nothingness/>.

Stambaugh, Joan (1996), Being and Time: A translation of Sein und Zeit (Albany, NY: State University of New York Press).

Wang, Zhongjiang (2001), Dao-Jia-Xing-Er-Shang-Xue [Daoist Metaphysics] (Shanghai: Shanghai-Wen-Hua-Chu-Ban-She).

Wirtz, Markus (2006), Geschichten des Nichts: Hegel, Nietzsche, Heidegger und das Problem der philosophischen Pluralität (Freiburg and München: Verlag Karl Alber).

Zhao, Weiwei (2007), "Lao-Zi-De-Wu-Yu-Zhong-Lun-De-Kong-Zhi-Yi-Tong” [Similarity and Differences between Nothing in the Lao-Zi and Emptiness in the Mūlamadhyamakakārikā], Zhong-Guo-Zhe-Xue-Yu-Wen-Hua [Journal of Chinese Philosophy and Culture] 2: 324-41. 